\title{
An Economic Analysis of Environmental Horticulture with a Focus on California
}

\author{
Scott R. Templeton', Cheryl Brown ${ }^{2}$, George E. Goldman ${ }^{3}$, Seung Jick Yoo ${ }^{4}$, and Vijay S. Pradhan \\ Department of Agricultural and Resource Economics and Policy, 207 Giannini Hall, MC \#3310, \\ University of California, Berkeley, CA 94720-3310
}

Additional index words. "green" industry, horticulture and landscaping services, expenditures, sales, jobs, landscape area, regional economics

Environmental horticulture involves the use of plants or planted landscapes to enhance indoor or outdoor human activity. Private benefits include pure aesthetic pleasure, recreation, safer playing surfaces and roadsides, stress reduction, quicker convalescence, higher workplace productivity (Beard and Green, 1994), lower cooling expenses because of shading (McPherson and Rowntree, 1993), and gains in property values (Henry, 1993). As income and population increase, the demand for activities dependent on environmental horticulture, e.g., golfing, increases (e.g., Johnson and Christensen, 1995). As the industry grows, more areas are converted into landscapes that often contain nonnative plants; are maintained through intensive use of water, mechanical, and chemical inputs; and are sources of green waste. Some land conversion, nonnative plants, intensive input use, and waste disposal can adversely affect environmental quality or human health (e.g., Balogh et al., 1992; Kross et al., 1996; Templeton et al., 1998). As a result, the industry is becoming more regulated (e.g., Environmental Protection Agency, 1996) but is not supported by governmental

Received for publication 28 June 1999. Accepted for publication 20 Dec. 1999. Preliminary results of this research were presented on 21 Feb. 1998 at the Western Regional Science Association's 37th Annual Meeting. This research was funded by the Elvinia J. Slosson Endowment Fund, the California Association of Nurserymen, the California Landscape Contractors Association, and the Horticultural Research Institute. National Gardening Association data for California were purchased with funds from a grant from the United States Environmental Protection Agency. The California Green Industry Council, Tom Bellows, Robin Brumfield, David Burger, Steve Cieslewicz, Kim Crum, Pete Dominguez, Jim Husting, Hap Kellogg, William Latham, Deborah Nolan, Dennis Pittenger, Larry Rohlfes, Jack Wick, and three anonymous reviewers provided helpful comments. We also thank Elizabeth Bernhardt and Tedmund Swiecki for previously sharing data on urban forestry. The cost of publishing this paper was defrayed in part by the payment of page charges. Under postal regulations, this paper therefore must be hereby marked advertisement solely to indicate this fact ${ }^{1}$ To whom reprint requests should be addressed. Current title and address: Assistant Professor, 259 Barre Hall, Department of Agricultural and Applied Economics, Clemson University, Clemson, SC 29634-0355.

${ }^{2}$ Assistant Professor, Dept. of Agriculture, Southeast Missouri State University.

${ }^{3}$ Economist, Cooperative Extension and member of the Giannini Foundation of Agricultural Economics. ${ }^{4}$ Research Fellow, Korea Energy Economics Institute, Euiwang-si, South Korea.

${ }^{5}$ Statistician, Cooperative Extension. and academic institutions to the degree that traditional agricultural producers are (e.g., Johnson and Christensen, 1995). Thus, upto-date and comprehensive economic information about environmental horticulture is important for determining the industry's contributions to the economy relative to those of other industries, assessing impacts of landuse or regulatory changes, and establishing priorities of policy makers.

The primary purpose of our research was to analyze the economy of environmental horticulture in California. Although the focus is on California, our research should be of general interest because, in all likelihood, no other state accounts for more of the national economic activity associated with environmental horticulture than does California. Moreover, some of the results about California can be used with auxiliary data to estimate sales and expenditures associated with environmental horticulture for the nation as whole. Finally, our estimation methods can be used for future research about other individual states, regions, or the nation.

Previous research for California (e.g., Pittenger et al., 1991) and, with few exceptions, for other states or the whole nation (e.g., Turner and Kriesel, 1995) has focused on marketed horticultural goods and services for which secondary data have been readily available. Many previous studies also have combined production or wholesale revenues with retail sales and, thereby, have overestimated economic impacts. The two most recent studies for California (Schuch and Klein, 1996; Templeton and Goldman, 1996) examined only segments of this economy. With few exceptions (e.g., Cox et al., 1991; Hodges et al., 1994), previous research also has not addressed spatial impacts or expenditures per unit area. No previous study has presented confidence intervals for estimators of economic size.

\section{SCOPE, DATA, AND METHODS}

In this study, we estimated total expenditures and sales (Table 1), jobs (Table 2), land area, and expenditures per unit area (Table 3 ) associated with management-maintenance, installation, and, in a few cases, design — of 12 landscape types in California for 1995 or a similar 12-month period. We also estimated expenditures on contractual management of green waste associated with environmental horticulture in 1995. (For brevity, we use "horticultural" for "environmental horticultural", which includes "floricultural" and "arboricultural".) Data covered both marketed horticultural goods and services and nonmarketed, or in-house, horticultural services.

Table 1. Annual expenditures and sales related to environmental horticulture in California.

\begin{tabular}{|c|c|c|c|c|}
\hline Landscape or plant type & Expenditures $(\$)^{z}$ & Sales $(\$)^{\mathrm{z}}$ & SD (\$) & $\mathrm{n}$ \\
\hline Residential yards subtotal: & 3,579 & $\leq 3,579$ & 510 & --- \\
\hline Do-it-yourself care and installation (1995) & 1,864 & $\leq 1,864$ & 329 & $101^{\mathrm{y}}$ \\
\hline Professional care and installation (1995) & 1,354 & 1,354 & 308 & $101^{\mathrm{y}}$ \\
\hline Landscape water (1991) & 361 & 361 & 46 & 60 \\
\hline Indoor environments (1995): Cut flowers & 1,429 & 1,429 & $\mathrm{NE}^{\mathrm{x}}$ & $\mathrm{NA}^{\mathrm{w}}$ \\
\hline Indoor environments (1995): Houseplants & 102 & 102 & 37 & 101 \\
\hline Indoor environments (1995): Christmas trees & 131 & 75 & $\mathrm{NE}$ & NA \\
\hline Golf courses $(1995)$ & 683 & 683 & $\mathrm{NE}$ & 169 \\
\hline State (FY96-97) and other parks (FY 94-95) & 600 & 600 & $\mathrm{NE}$ & NA \\
\hline City streets and other right-of-ways (FY 94-95) & 218 & 218 & 0 & 470 \\
\hline State highways (FY 94-95) & 108 & 108 & 0 & 1 \\
\hline School yards (FY 94-95) subtotal: & 312 & 312 & 57 & 55 \\
\hline Public and private, $\mathrm{K}-12$ & 286 & 286 & 57 & 36 \\
\hline Universities, CSU and UC & 27 & 27 & 2 & 19 \\
\hline Electric utility vegetation (1995) & 147 & 147 & 22 & 5 \\
\hline Cemeteries (1995) & 141 & 141 & 25 & 72 \\
\hline Arboreta and botanical gardens (1995) & 13 & 13 & 4 & 12 \\
\hline Zoos (1995) & 7 & 7 & 4 & 5 \\
\hline Other landscapes in California (1994) & 467 & 467 & NE & NA \\
\hline Horticultural waste (1995) & 582 & 582 & NE & NA \\
\hline Out-of-state landscapes (1994) & --- & 1,645 & $\mathrm{NE}$ & NA \\
\hline Total & 8,518 & 10,108 & 528 & --- \\
\hline
\end{tabular}

${ }^{\mathrm{z}}$ Millions of 1995 dollars.

yThe sample size is $<127$ because of "don't know" responses.

${ }^{\mathrm{x}} \mathrm{NE}=$ not estimable with available data.

${ }^{\mathrm{w}} \mathrm{NA}=$ not available. 
Table 2. Annual employment in environmental horticulture in California.

\begin{tabular}{lccr}
\hline & No. of & \multicolumn{2}{c}{ Sample } \\
\cline { 2 - 4 } Employer & jobs & SD & Size \\
\hline Professional horticultural services (1995) & 54,015 & $\mathrm{NE}^{z}$ & $\mathrm{NA}^{\mathrm{y}}$ \\
Retail florists (1995) & 10,850 & $\mathrm{NE}$ & $\mathrm{NA}$ \\
Retail nurseries, lawn and garden stores (1995) & 8,125 & $\mathrm{NE}$ & $\mathrm{NA}$ \\
Growers of flowers and ornamental plants (1995) & $9,756^{\mathrm{x}}$ & $\mathrm{NE}$ & $\mathrm{NA}$ \\
Manufacturers of lawn and garden equipment (1995) & $95^{\mathrm{x}}$ & $\mathrm{NE}$ & $\mathrm{NA}$ \\
City, county, two federal parks (FY 94-95) & & & \\
$\quad$ and state parks (FY 96-97) & 9,871 & 394 & $295^{\mathrm{w}}$ \\
Golf courses (1995) & 13,470 & $\mathrm{NE}$ & $\mathrm{NA}$ \\
City and state roadway agencies & 4,401 & 144 & 261 \\
City street agencies (1995) & 3,663 & 144 & $260^{\mathrm{w}}$ \\
CALTRANS (FY 94-95) & 738 & 0 & 1 \\
Schools (FY 94-95) subtotal: & 14,288 & 2,816 & 57 \\
Public and private K-12 & 13,616 & 2,816 & 38 \\
Public universities, CSU and UC & 672 & 33 & 19 \\
Electric utilities (1992) & 272 & 84 & 5 \\
Cemeteries (1995) & 3,218 & 609 & 74 \\
Arboreta and botanical gardens (1995) & 331 & 54 & 13 \\
Zoos (1995) & 150 & 73 & 5 \\
Total & 128,842 & 2,914 & --- \\
\hline
\end{tabular}

${ }^{2} \mathrm{NE}=$ not estimable within available data.

${ }^{y} \mathrm{NA}=$ size of original sample is not available.

${ }^{\mathrm{X}} \mathrm{Jobs}$ attributable to exports.

w260 and 33 observations on city and county urban forestry.

Table 3. Area and expenditure intensity for environmental horticulture in California.

\begin{tabular}{|c|c|c|c|c|}
\hline Landscape type & $\begin{array}{c}\text { Area } \\
\text { (ha) }\end{array}$ & $\begin{array}{l}\text { SD } \\
\text { (ha) }\end{array}$ & $\begin{array}{c}\text { Sample } \\
\text { size for } \\
\text { area }\end{array}$ & $\begin{array}{c}\text { Expenditure } \\
\text { per unit } \\
\text { area }(\$ / \mathrm{ha})\end{array}$ \\
\hline Private residential yards (1995) & 274,960 & 33,441 & 83 & 13,016 \\
\hline Golf courses (1995) & 53,059 & $\mathrm{NE}^{\mathrm{z}}$ & $\mathrm{NA}^{\mathrm{y}}$ & 12,866 \\
\hline Flower and ornamental plant farms (1992) & 27,165 & $\mathrm{NE}$ & census & $53,546^{x}$ \\
\hline City, county, and two federal parks (FY 94-95) & 63,815 & $\mathrm{NE}$ & NA & 9,350 \\
\hline City and state roadways subtotal: & 29,125 & 158 & 459 & 10,712 \\
\hline City streets (1995) & 19,907 & 158 & 458 & 10,259 \\
\hline State highways (FY 94-95) & 9,218 & 0 & 1 & 11,689 \\
\hline School yards (FY 94-95) subtotal: & 44,091 & 6,197 & 61 & 7,084 \\
\hline Public and private $\mathrm{K}-12$ & 40,570 & 6,188 & 37 & 7,040 \\
\hline Public universities, CSU and UC & 3,521 & 344 & 24 & 7,597 \\
\hline Vegetation around electric power lines (1995) & 63,827 & 15,814 & 3 & 2,303 \\
\hline Cemetery grounds (1995) & 7,257 & 1,156 & 76 & 19,420 \\
\hline Arboreta and botanical gardens (1995) & 459 & 103 & 13 & 28,955 \\
\hline Zoo grounds (1995) & 284 & 135 & 5 & 25,523 \\
\hline Total $^{\mathrm{w}}$ & $\overline{554,087}$ & $\overline{37,526}$ & $\overline{---}$ & $\overline{13,077}$ \\
\hline
\end{tabular}

${ }^{2} \mathrm{NE}=$ not estimable with available data

${ }^{y} \mathrm{NA}=$ size of original sample is not available

×Based on 1992 revenues stated in 1995 dollars (Bureau of the Census, 1994).

${ }^{\text {w}}$ Total area does not include one-half of the area of roadside vegetation managed by city governments because the landscape below power lines within cities, the area of which is already included, parallels one side of a road.

Unless indicated otherwise, expenditures were also within-state sales. We also used the information about California and other data to estimate the size of the horticultural economy for the nation in 1995 and the state in 1998. To avoid double-counting, we focused on transactions at the export, retail, or final-user level. We estimated confidence intervals when data permitted.

Primary data were collected from the following sources: the household survey of the National Gardening Association (NGA) for 1995 that was augmented with questions about yard size; the State Controller's Office (Connell, 1997a); surveys of California State University campuses (National Association of College and University Business Officers, 1996); our update of a previous survey of electric utilities; the 1992 California Commu-

professional organizations, and the 1994 IMPLAN database. (The database is usually not identified by the words for which IMPLAN stands: IMpact Analysis for PLANning.)

Estimators of characteristics of the horticultural economy and variances of these estimators reflect the finite number of decisionmakers within that economy. For example, an unbiased, mean-based estimator of total expenditures, jobs, or land area, if any, associated with private residential yards, houseplants, school yards, cemeteries, arboreta, and zoos is

$$
\hat{Y}_{j}=N_{j} \bar{y}_{j}
$$

in which $N_{j}$ is the finite number of decisionmakers, e.g., zoo operators, for landscape type $j$, e.g., zoo grounds, and $\bar{y}_{j}$ is the sample mean of the characteristic of interest, e.g., area, for type $j$, (Cochran, 1977). An unbiased estimator of the variance of this estimator is

$$
v\left(\hat{Y}_{j}\right)=N_{j}^{2} \frac{s_{j}^{2}}{n_{j}} \frac{\left(N_{j}-n_{j}\right)}{N_{j}}
$$

in which

$$
s_{j}^{2} \equiv \sum_{i=1}^{n_{j}} \frac{\left(y_{i j}-\bar{y}_{j}\right)^{2}}{n_{j}-1}
$$

$$
n_{j}=\text { sample size for } j \text {, and } \frac{\left(N_{j}-n_{j}\right)}{N_{j}}
$$

is the finite population correction (Cochran, 1977). A consistent, ratio-based estimator of the area of roadside vegetation in California's cities in 1995 is

$$
\hat{Y}_{\hat{R}} \equiv X \hat{R} \equiv X \frac{\bar{y}}{\bar{x}}
$$

in which $X$ is the total number of people in these cities in 1995, and $\bar{x}$ and $\bar{y}$ are the respective mean number of people and hectares in a 1991 sample. A frequently used estimator of the variance of this estimator (Cochran, 1977) is

[Eq. 5]

$$
v\left(\hat{Y}_{\hat{R}}\right) \cong N^{2}\left(\frac{N-n}{N}\right) \frac{1}{n} \frac{\sum_{i=1}^{n}\left(y_{i}-\hat{R} x_{i}\right)^{2}}{n-1}
$$

In the ratio-based estimators of characteristics of electric utilities, $X$ is the total number of their customers in the market in 1991, $\bar{x}$ is mean customers in 1991, and $\bar{y}$ is mean expenditures, in-house jobs, or area of landscape under electric power lines in 1995 of utilities in the sample.

Ratio-based estimators of three characteristics utilize auxiliary data. In particular, let $X_{j k}$ and $Y_{j k}$ be horticultural expenditures and jobs, respectively, in which $k=$ city or county if $j=$ parks, and $k=$ city if $j=$ street landscapes. Let $W_{k}$ and $Z_{k}$ be arboricultural expenditures and jobs, respectively, associated with $k$ (= city or county) government's management of trees along streets and in parks. Assume

$$
\frac{Y_{j k}}{X_{j k}}=\frac{Z_{k}}{W_{k}}
$$


[Eq. 7]

$$
v\left(X_{j k} \frac{\bar{z}_{k}}{\bar{w}_{k}}\right) \cong X_{j k}^{2} \frac{\left(N_{k}-n_{k}\right)}{N_{k}} \frac{1}{\bar{w}_{k}^{2}} \frac{1}{n_{k}} \frac{\sum_{i=1}^{n_{k}}\left(z_{i k}-\hat{R}_{k} w_{i k}\right)^{2}}{n_{k}-1}
$$

\section{RESULTS}

Private residential yards. There were 10.97 million households in all types of dwellings in the state in 1995 (Department of Finance, 1996). According to responses of California residents who were randomly selected without regard to dwelling type to participate in the NGA's annual survey ( $\mathrm{n}=$ 127 ), $80 \%$ of all households had lawns, gardens, or other planted areas that covered a total of 274,960 ha. These households spent $\$ 1.864$ billion on do-it-yourself yard activities and $\$ 1.185$ billion for professional lawn care, landscape maintenance, and tree care in 1995. Owners of 85,293 new residences in 1995 (Real Estate Research Council of Northern California, 1999) paid an average of $\$ 1983$ per unit, according to three real-estate developers, or \$169 million for professional installation of their front yards. Also, households spent \$361 million (1995 dollars) on water for their yard plants in 1991, a drought year (Department of Water Resources, 1994). Thus, households spent an estimated total of $\$ 3.579$ billion on planted yards in 1995 .

Indoor environments. Californians spent $\$ 1.661$ billion on plants for indoor decoration, $\$ 1.605$ billion of which circulated within the state economy. Most of these expenditures were for cut flowers and greens. In particular, 4914 florists had retail sales of $\$ 714$ million in 1995 (State Board of Equalization, 1996). Home centers, discount stores, supermarkets, and other diversified retailers represent at least half of the cut flower market, according to professional judgment $(\mathrm{H}$. Kellogg, personal communication) and evidence regarding related products (Templeton et al., 1998). Given an assumption that the $\$ 714$ million for florists represented only $50 \%$ of the total market, retail sales of cut flowers and greens were $\$ 1.429$ billion in 1995.

People also use potted plants and Christmas trees. According to NGA data, $21 \%$ of all households in California cared for indoor houseplants and spent $\$ 102$ million for the purchase of these plants, their care, or both in 1995. Of all households in California and other states in the "West", 48\% purchased real Christmas trees and paid $\$ 25$, on average, per tree (National Christmas Tree Association, 1996). If one assumes that these figures apply to California, the state's households spent \$131 million for these trees. Since California growers sold $\$ 19$ million of cut-and-carry Christmas trees (Department of Food and Agriculture, 1996), the remaining \$112 million was spent on imported real Christmas trees, primarily from Oregon. Given the typical retail markup of $100 \%$ (M. Wade, personal communication), $50 \%$ of this remainder, or $\$ 56$ million, stayed within the state. Thus, a total of $\$ 75$ million of house- hold spending on Christmas trees stayed within the state's economy.

Golf courses. In 1995, California had 898 golf courses, 306 private and 592 public (M. Phalen, personal communication). Private and public golf courses in the western United States spent, on average, $\$ 771,330$ and $\$ 645,583$ for landscape maintenance and $\$ 87,945$ and $\$ 63,424$ for landscape-related capital expenses, respectively, in 1995 (Golf Course Superintendents Association of America, 1996). Based on the assumption that these averages also are those of California, golf courses in the state spent $\$ 618.2$ million for maintenance and $\$ 64.5$ million for capital expenses, or $\$ 683$ million for horticulture in 1995. The median size of private, 18 -hole courses in the state was 59.1 ha and the median number of employees was 15 in 1995 (M. Phalen, personal communication). Based on an assumption that these figures are mean employment and planted area for all courses in California, horticultural management of these courses entailed 13,470 jobs and course vegetation covered 53,059 ha.

Public parks. California had 23 national and 277 state parks in mid-1995 (Department of Finance, 1996). Although national and state parks covered 3.28 and 0.543 million ha, respectively (Department of Finance, 1996), only small portions were horticultural landscapes. For example, Golden Gate National Recreation Area and Muir Woods National Monument account for 29,618 and 224 ha, respectively (Department of Finance, 1996), but had only 99 and 4 ha of maintained landscapes (N. Weeks, personal communication). City, county, and district parks numbered 7738 and covered more than 63,712 ha in 1987 (Dangermond and Associates, 1989). These public parks, in total, covered at least 63,815 ha in 1995 .

Agencies that manage public parks in California spent an estimated $\$ 600$ million on horticulture in FY 94-95. The federal government spent \$1.2 million for horticultural landscapes in the Golden Gate National Recreation Area and MuirWoods National Monument(N. Wood, personal communication). The state's Department of Parks and Recreation spent \$0.5 million for landscape maintenance materials in FY 96-97 (V. Bradshaw, personal communication). Under the assumption that this expense represents $15 \%$ of total expenses, which also include irrigation, labor, and administration (Dangermond and Associates, 1989), the Department spent \$3.3 million (1995 dollars) for maintenance of landscapes in state parks. Local governments reported expenditures of $\$ 1.337$ billion for city parks and recreation (Connell, 1997a) and \$175 million for county recreational facilities (Connell, 1997b). According to three parks and recreation officials, local governments spend $39 \%$ of their budgets and, by implication, spent almost $\$ 526.6$ million and \$68.9 million in FY 94-95 for horticulture at city and county parks.

Data from Bernhardt and Swiecki (1993) indicate that city and county agencies had 1.7 and 1.4 full-time equivalent (FTE), in-house jobs, respectively, per $\$ 100,000$ of expendi- ture for arboriculture. Given these ratios, the expenditures of cities and counties for horticulture imply the equivalent of 8819 ( $n=260$, $\mathrm{SD}=347)$ and $970(\mathrm{n}=33, \mathrm{SD}=186)$ full-time jobs. Based on an assumption that the unknown ratio for state parks is the same as the ratio for county parks, the expenditure of the Department of Parks and Recreation implies 47 FTEs $(n=33, s D=9)$ for landscape maintenance at state parks. The two federal parks surveyed had the equivalent of 35 full-time jobs in FY 95-96. In total then, people worked the equivalent of 9871 full-time jobs related to horticulture in city, county, state, and two federal parks.

Roadside and other right-of-way vegetation. City governments and the California Department of Transportation (CALTRANS) spent $\$ 326$ million for design, installation, and maintenance of 29,125 ha of vegetation along roadsides or other right-of-ways and engaged in horticultural-related work that was the equivalent of 4401 full-time, in-house jobs. These estimates break down as follows. CALTRANS spent \$108 million in FY 94-95 to manage 9218 ha of landscapes along roads with the equivalent of 738 full-time positions for landscape design, installation, and maintenance (L. Coe and L. Shields, personal communication). City governments spent $\$ 204.2$ million for street trees and roadway-related landscaping and \$14.5 million on weed abatement in FY 94-95 (Connell, 1997a). Given 1.7 full-time equivalent, in-house jobs per $\$ 100,000$ of arboricultural expense by cities, the expenditure of $\$ 219$ million implies 3663 full-time equivalent jobs. Given the population in California's 470 cities in 1995 (Connell $1997 \mathrm{a}$ ), a ratio of $4.13 \mathrm{~km}$ of road per 1000 city residents in 1991 (Bernhardt and Swiecki, 1993), and an assumption that the planted landscape strip is $0.9 \mathrm{~m}$ wide on each side of a road, managed vegetation along city streets covered 19,907 ha.

School yards. Planted landscapes beautify schools, enable recreation, and enhance educational environments. The University of California (UC) and California State University (CSU) had more than 500,000 students and almost 180,000 faculty and staff, all of whom are potential consumers of campus landscapes. According to survey responses and the $\mathrm{Na}-$ tional Association of College and University Business Officers (1996), facilities and grounds superintendents at nine UC and twenty CSU campuses spent \$26.7 million in FY 94-95 to manage 3521 ha of horticultural landscapes with the equivalent of 672 full-time, in-house jobs. According to survey responses, 993 public school districts (Connell, 1997c) and 4152 private schools (C. Calderone, personal communication) employed people to fill the equivalent of 13,616 full-time jobs and spent \$285.6 million for installation and maintenance of 40,570 ha of planted school yards in FY 94-95. In total, public universities and all $\mathrm{K}-12$ schools in the state spent $\$ 312$ million to manage 44,091 ha of horticultural landscapes with the equivalent of 14,288 full-time employees, including associated supervisors and administrators. 
Vegetation around electric power lines. Prior to recent deregulation, California had 37 electric utilities, but five of them accounted for 93\% of all customers (Fay, 1991). These utilities or their contractors regularly inspect a 6-m diameter, aerial corridor around power lines for intrusions of tree branches, prune back branches that are too close, and remove all vegetation on the ground within $3 \mathrm{~m}$ of power poles in accordance with fire and safety regulations (S. Cieslewicz, personal communication). In 1995, electric utilities spent $\$ 147$ million for these and other arboricultural activities, \$114 million of which was for contractual work. These utilities had 272 full-time equivalent, in-house arboricultural jobs. Two of the five utilities had in-house tree crews. All 37 supervised or provided support services for in-house or contractual tree crews.

Based on responses from three of the largest five utilities, the estimated total lengths of distribution and transmission lines in 1995 were 316,363 and $40,821 \mathrm{~km}$, respectively. Assume that the 6-m diameter aerial corridor around transmission lines translates into a vegetative strip on the ground of at least the same width, because these lines typically run through forests, pastures, deserts, and other areas with vegetation. Also assume that the aerial corridor around distribution lines translates into a $1.2-\mathrm{m}$ wide vegetative strip because of roads, sidewalks, driveways and other hardscape in urban areas. Given these assumptions, the vegetative area for which utilities were responsible was 63,827 ha. (The 32 utilities that accounted for $7 \%$ of all customers in 1991 were treated as one unit for statistical purposes).

Cemeteries. Cemetery grounds beautify burial sites. The Cemetery Licensing Board and telephone, religious, and internet directories listed 198 licensed and 356 unlicensed cemetery operators in California in 1996. These operators employed people for 3218 full-time equivalent, horticultural jobs and spent $\$ 141$ million on installation and maintenance, including irrigation, of 921 cemeteries $(n=77$, $\mathrm{SD}=81$ ) that occupied 7257 ha in 1995.

Arboreta and botanical gardens. Arboreta and botanical gardens provide recreation, education, and, in some cases, ex situ conservation of genetic material. California's 51 arboreta and botanical gardens had horticultural expenses of $\$ 13$ million, 459 ha of managed vegetation, and 331 full-time equivalent, horticultural jobs.

Zoos. Planted landscapes enhance recreation for people who visit zoos and habitat for some of the animals. California's 18 zoos spent $\$ 7.25$ million to have the equivalent of 150 fulltime employees manage 284 planted hain 1995.

Other horticultural landscapes in California. Airports, hotels, hospitals, business parks, and numerous other organizations paid $\$ 467$ million (1995 dollars) for contractual design, installation, and maintenance of planted landscapes around their facilities in 1994 (Table 1). This estimate is the inflation-adjusted sales of landscape-and-horticultural-service companies (IMPLAN sector 27) to all other domestic IMPLAN sectors except owner- occupied dwellings (sector 461), funeral homes (sector 467), schools (sectors 495-497 and 522), electric utilities (sectors 443 and 511), state and local government (sectors 512 and 523), and buyers outside of California (Minnesota IMPLAN Group, 1997). This estimate also includes $\$ 0.26$ million of sales of lawn and garden equipment (sector 310) to the federal government (Minnesota IMPLAN Group, 1997).

Horticultural waste. Californians spent $\$ 582$ million for contractual management of horticultural waste in 1995 (Table 1). In particular, the California Integrated Waste Management Board estimates that 4.44 million $t$ of horticultural waste were disposed of as trash at landfills, 0.831 million $t$ were composted at composting facilities, and 0.355 million $t$ were used as alternative daily cover at landfills in 1995 (C. Schmidle, unpublished data). The average cost of collecting yard waste, if mixed with other trash that went to landfills, was $\$ 74 / t$ in 1995 in the United States (Allied Composting Council, 1996). The weightedaverage tipping fee for horticultural waste disposed as trash or alternative daily cover at landfills in the state was $\$ 34.20 / t$ in 1995 (Kakutani, 1995). The average cost of collecting yard waste that was separated from other trash and, by implication, used for composting or alternative daily cover was $\$ 60 / t$ in 1995 in the United States (Allied Composting Council, 1996). Composting facilities in California and four other western states charged, on average, $\$ 6.97 / \mathrm{m}^{3}$ to accept yard waste in 1995 (Markets Page $^{\mathrm{TM}}$, 1996). Given $\approx 0.30 \mathrm{t} \cdot \mathrm{m}^{-3}(\mathrm{~T}$. Padia, Alameda County Waste Management Authority, personal communication), this charge is equivalent to $\$ 23.37 /$ t. Hence, in 1995, Californians spent $\$ 479$ million for collection of yard waste and its disposal as trash at landfills, $\$ 69$ million for its collection and disposal at composting facilities, and \$33 million for its collection and use as alternative daily cover.

Out-of-state landscapes. Nurseries, flower growers, and others sold $\$ 1.619$ billion of horticultural goods and services to customers outside of California in 1994, or $\$ 1.645$ billion in 1995 prices (Table 1). The 1994 estimate is the sum of four sub-estimates. Providers of "landscape and horticultural services" and manufacturers of yard-care equipment had exports of $\$ 874$ million and $\$ 7.3$ million, respectively, in 1994, primarily to other states (Minnesota IMPLAN Group, 1997). California growers of flowers and nursery products had sales of $\$ 2.172$ billion in 1995 (Department of Food and Agriculture, 1996). Since $17 \%$ was sales of vegetable, fruit, and nut plants (California Agricultural Statistics Service, 1996), these producers sold $\$ 1.797$ billion worth of ornamental plants. [In contrast, California farmers sold $\$ 20.3$ billion worth of agricultural crops (California Agricultural Statistics Service, 1996; Department of Food and Agriculture, 1996).] Exports of horticultural crops to buyers outside of the United States, exclusive of mushroom spawns and edible fruit or nut trees, were $\$ 22$ million in 1995 (Department of Food and Agricul- ture, 1996). If domestic and foreign exports represent $41 \%$ of sales, the average of three such percentages in the literature (Minnesota IMPLAN Group, 1997; Schuch and Klein, 1996), then growers sold $\$ 715$ million worth of ornamental plants to buyers in other states.

Other jobs. The full-time equivalent jobs already estimated, a total of 46,001, are directly associated with in-house provision of horticultural services. Market provision of landscape and horticultural services (SIC 078) entailed an additional 54,015 jobs (Rose, 1998). Also, sales of horticultural goods directly accounted for 28,826 jobs. In particular, there were 10,850 jobs with florists (SIC 5992) and 8125 jobs at lawn and garden centers and retail nurseries (SIC 5261) in 1995 (Rose, 1998). Farmgate sales of nursery products and flowers supported 28,753 jobs in 1995 (Rose, 1998). (In comparison, total agricultural crop production supported 351,496 jobs in the same year (Rosenberg, 1997).) Manufacture of lawn and garden equipment (SIC 3524) entailed 662 jobs in 1995 (Rose, 1998). However, only 9756 and 95 jobs, respectively, can be directly attributed to exports of horticultural products and to sales of lawn and garden equipment to the federal government and buyers outside of California. Not all of these jobs are necessarily full-time because official data include temporary, part-time, and seasonal positions.

\section{DISCUSSION}

Economic impacts. At the export, retail, or final-user level, Californians spent $\$ 8.518$ billion and had sales of $\$ 10.108$ billion for horticultural goods and services in or close to 1995 (Table 1). The $95 \%$ confidence interval is plus or minus $\$ 1.035$ billion of these estimates. In contrast, Californians spent $\$ 64.2$ billion for food in 1995 and sold $\$ 68.5$ billion (1995 dollars) of food in 1996 (Templeton et al., 1999). The difference between expenditures and sales is net exports to other states or countries. These sales directly entailed 128,842 jobs (Table 2). The $95 \%$ confidence interval is 123,130 to 134,554 jobs. These sales directly translated into $\$ 6.971$ billion in household income (Minnesota IMPLAN Group, 1997). The 95\% confidence interval is plus or minus $\$ 716$ million of this estimate. These economic impacts are probably larger in California than other states because it has one of the longest growing seasons and the biggest population and economy among states in the nation (Bureau of the Census, 1996).

In addition to these direct economic impacts, environmental horticulture also generates "indirect" and "induced" impacts when, at prevailing prices, exports of horticultural goods and services from California increase or imports decrease with corresponding increases in purchases of goods and services produced within the state. In particular, a $\$ 100$ million increase in net exports of nursery products, horticultural services, or lawn and garden equipment generates respective additional impacts of $\$ 122, \$ 208$, or $\$ 74.6$ million in sales and total impacts of $\$ 134, \$ 183$, or $\$ 67.4$ million in total income 
(Minnesota IMPLAN Group, 1997). These additional impacts occur because businesses that supply inputs, e.g., fertilizers, to those who sell horticultural goods and services at the export or final-user level also purchase products from other businesses, and people spend most of the income that they earn from these input suppliers and other businesses.

These estimates understate the size of the horticultural economy in the state, however. For example, expenditures and jobs associated with in-house provision of horticultural services for "other landscapes in California" and jobs associated with contractual management of green waste were not estimable for lack of data. Market expenditures for "other landscapes in California" and "outof-state landscapes" were estimated with IMPLAN data, which understate purchases of landscape and horticultural services (e.g., Templeton and Goldman, 1996). Also, the available data did not permit a breakdown of expenditures between marketed and nonmarketed horticultural services for landscapes other than private residential yards and vegetation around electric power lines. By filling these information gaps with more detailed, primary data, researchers can better estimate the overall size, internal makeup, and changes of the horticultural economy.

Horticultural landscape area. There were 554,087 ha of horticultural landscapes (Table 3 ). The $95 \%$ confidence interval is 480,537 to 627,637 ha. This area is primarily for "consumption" activities. In 1992, production of floricultural crops, bulbs, nonvegetable and nonfruit nursery crops, sod, and flower seeds covered 27,165 ha: 25,909 ha outdoors and 1256 ha under glass or other protection (Bureau of the Census, 1994; California Agricultural Statistics Service, 1996). In contrast, harvested cropland covered 3.114 million ha in 1992 (Bureau of Census, 1994). The estimate of 554,087 ha does not, however, include the area of "other landscapes in California". Future estimation should include areas of maintained grounds in all federal and state parks, roadside vegetation managed by counties, turf at sports facilities and airports, and landscapes around corporate offices, retail shopping centers, hospitals, hotels, and amusement parks. Estimation of the proportion of horticultural landscapes that are irrigated or receive chemical treatments should also be the subject of future research.

Expenditure intensity. Expenditure intensities for horticultural landscapes have an interesting economic pattern (Table 3). Let $R$ and $R_{k}$ be expenditures per hectare for landscapes $j \neq k$. Under the null hypothesis that these ratios are equal and the two samples come from one underlying population, the $t$ statistic with $n_{j}-n_{k}-2$ df is

$$
\frac{\hat{R}_{j}-\hat{R}_{k}}{s \sqrt{\frac{1}{n_{j}}+\frac{1}{n_{k}}}}
$$

in which

$$
s=\sqrt{\frac{\left(n_{j}-1\right) s_{j}^{2}+\left(n_{k}-1\right) s_{k}^{2}}{n_{j}+n_{k}-2}}
$$

and

$s_{j}^{2} \equiv v\left(\hat{R}_{j}\right) \equiv v\left(\frac{\bar{y}_{j}}{\bar{x}_{j}}\right) \cong \frac{\left(N_{j}-n_{j}\right)}{N_{j}} \frac{1}{\bar{x}_{j}^{2}} \frac{1}{n_{j}} \frac{\sum_{i=1}^{n_{j}}\left(y_{i j}-\hat{R}_{j} x_{i j}\right)^{2}}{n_{j}-1}$

54 ha, then expenses per hectare would be $\$ 14,078$ instead of $\$ 12,866$. Either figure underestimates management intensity on greens, tees, and fairways because roughs account for two-thirds to three-fourths of the vegetative area but receive the least care (Balogh et al., 1992).

Estimated national economy and recent state growth. Households nationwide spent $\$ 34.787$ billion in 1995 for yard-related horticulture, except water, and indoor houseplants. This figure consists of $\$ 20.587$ billion for do-it-yourself activities (National Gardening Association, 1996) and $\$ 14.2$ billion for professional services (National Gardening Association, unpublished data). Californians spent $\$ 3.320$ billion for yards, except water, and indoor plants (Table 1), or $9.5 \%$ of the national figure. If this percentage is, on average, California's share of national expenditures for other horticultural landscapes and cut flowers, total statewide expenditure of $\$ 8.518$ billion implies that people in the United States spent $\$ 89.252$ billion for environmental horticulture in 1995. Since net imports of flowers and nursery products were $\$ 616$ million (Economic Research Service, 1996), the industry of environmental horticulture contributed an estimated $\$ 88.636$ billion in 1995 to the gross domestic product of the United States.

California's horticultural economy has probably grown since 1995 . If the state's 258,517 new households (Department of Finance, 1999) were the same, on average, as sample households, then the data in Tables 1 and 3 imply that Californians in 1998 spent an additional \$39 million (1995 dollars) for indoor plants and $\$ 84$ million (1995 dollars) for new residential yards that occupied 6482 ha. Real income per capita increased $7.9 \%$ during 1995-1998 (Bureau of Economic Analysis, 1999; B. Annis, personal communication). For each $1 \%$ increase in real household income, households spend $0.75 \%$ to $1.5 \%$ more for horticultural goods (Gineo and Omamo, 1990). If people spend $1 \%$ more, the data in Table 1 imply a separate increase of $\$ 423$ million in expenditures (1995 dollars) for yardrelated horticulture and plants for indoor environments. In response to growth of population and real per capita income, then, sales of products and services for yards and indoor plants increased an estimated $\$ 540$ million. The data in this paper also imply that California's 57 new golf courses (M. Phalen, personal communication), if identical on average to previously existing courses, spent at least \$43 million (1995 dollars) for horticulture and covered 3368 ha in 1998. Electric utilities spent an estimated \$121 million (1995 dollars) more for arboriculture in 1998 because a new regulation requires more clearance around power lines, and tree growth substantially increased 2 to 3 years after the drought ended (S. Cieslewicz, personal communication). In real terms (1995 dollars), then, estimated horticultural expenditures and sales of Californians increased $\$ 0.71$ billion between 1995 and 1998. In nominal terms, expenditures and sales were $\$ 9.81$ billion and $\$ 11.5$ billion in 1998 . 


\section{CONCLUSIONS}

The methods and results of this study are important. The methods can be used to estimate economic impacts of environmental horticulture in other states or the nation as a whole. The sales and job information can be and have already been used to assess potential magnitudes of growth of marketed horticultural goods or services and to develop business plans. The estimates of areas of different horticultural landscapes can improve planning for water conservation (Department of Water Resources, 1998) and regulation of environmental risks of pesticide or fertilizer use (Balogh et al., 1992). Water or chemical "requirements" for different landscapes can be multiplied by their corresponding statewide areas and reasonable percentages of areas that are irrigated or treated to obtain estimates for water or chemical use in total or by landscape type.

Expansion of residential yards, golf courses, and other horticultural landscapes occurs through contraction of habitat and, in some cases, economic activity associated with agricultural farms (Medvitz, 1998), wetlands (Balogh et al., 1992), forests, or other landscapes. Habitat alteration, green waste disposal, and use of pesticides and fertilizers, leaf blowers, lawn mowers, nonnative plants, and water on horticultural landscapes have become contentious policy issues. Policy makers can use our results to broadly assess net economic impacts of changes in land use or policies that affect management of horticultural landscapes in California and judge them in light of any associated impacts on the environment and human health. Moreover, private and public policy makers could use our results to justify allocating more resources for research, product development, education, extension, and regulation that could resolve these contentious issues and enable the horticultural industry to continue its economic growth.

\section{Literature Cited}

Applied Compost Consulting. 1996. Cost-benefit analysis of home composting programs in the United States. The Composting Council, Alexandria, Va., May.

Balogh, J.C., V.A. Gibeault, W.J. Walker, M.P. Kenna, and J.T. Snow. 1992. Background and overview of environmental issues, p. 1-37. In: J. C. Balogh and W. J. Walker (eds.). Golf course management and construction: Environmental issues. Lewis Publishers, Chelsea, Mich.

Beard, J.B. and R.L. Green. 1994. The role of turfgrasses in environmental protection and their benefits to humans. J. Environ. Quality 23(3):452-460.

Bernhardt, E. and T.J. Swiecki. 1993. The state of urban forestry in California-1992. Urban Forestry Program, California Dept. Forestry Fire Protection, December.

Bureau of Economic Analysis. 1999a. Gross state product. Bur. Econ. Analysis, U.S. Dept. Commerce, Washington, D.C. http://www.bea. doc.gov/ bea/regional/gsp/gspsum_c.htm.

Bureau of Economic Analysis. 1999b. Table 1-Per capita personal income by state and region, 1994-1998, Bur. Econ. Analysis, U.S. Dept. Commerce, Washington, D.C. http://
www.bea.doc.gov/bea/regional/pi.htm\#Table1.

Bureau of the Census. 1996. Statistical abstract of the United States 1996, 116th ed., Bur. Census, U.S. Dept. Commerce, Washington, D.C., October.

Bureau of the Census. 1994. 1992 Census of agriculture, Vol. 1, Part 5, California state and county data. Bur. Census, U.S. Dept. Commerce, Washington, D.C.

California Agricultural Statistics Service. 1996. 1995 Agricultural commissioners' data. California Agr. Stat. Serv., Agr. Stat. Branch, Dept. Food Agr., State of California, Sacramento, August.

California Department of Transportation. 1992. Assembly of statistical reports, 1991. Office of Federal Reporting and Analysis, Div. Highways, California Dept. Transportation, Sacramento, November.

Cochran, W.G. 1977. Sampling techniques, 3rd ed. Wiley, New York.

Connell, K. 1997a. Financial transactions concerning cities of California: Annu. Rpt., 1994-95 fiscal year. Controller of the State of California, Sacramento, June.

Connell, K. 1997b. Financial transactions concerning counties of California: Annu. Rpt., 1994-95 fiscal year. Controller of the State of California, Sacramento, June.

Connell, K. 1997c. Financial transactions concerning school districts of California: Annu. Rpt., 1994-95 fiscal year. Controller of the State of California, Sacramento, June.

Cox, L.J., J.R. Hollyer, and D.M Schug. 1991. An economic profile of Hawaii's landscape services. Res. Ext. Ser. No. 128, Hawaii Inst. Trop. Agr. Human Resources, Univ. Hawaii, Manoa.

Dangermond and Associates. 1989. The environmental horticulture industry: Its value to the state of California. Sacramento, August.

Department of Finance. 1999. Table 2: County/state population and housing estimates. Demographic Res. Unit, Dept. Finance, State of California, 1 Jan., http://www.dof.ca.gov/html/Demograp/E5text.htm.

Department of Finance. 1996. California statistical abstract-1996. Dept. Finance, State of California, Sacramento, November.

Department of Food and Agriculture. 1996. 1996 California agricultural resource directory. Office of External Affairs, Dept. Food and Agr., State of California, Sacramento.

Department of Water Resources. 1998. California water plan update. Bul. 160-98. Dept. of Water Resources, The Resources Agency, State of California, Sacramento, November.

Department of Water Resources. 1994. Urban water use in California. Bul. 166-4. Dept. of Water Resources, The Resources Agency, State of California, Sacramento, August.

Economic Research Service. 1996. Foreign agricultural trade of the United States, calender year 1995 supplement. Commercial Agr. Div., Econ. Res. Serv., U.S. Dept. Agr., June.

Environmental Protection Agency. 1996. Major issues in the Food Quality Protection Act of 1996. Office of Prevention, Pesticides and Toxic Substances, U.S. Environ. Protection Agency, Washington, D.C., August.

Fay, J.S (ed.). 1991. California almanac, 5th ed. Pacific Data Resources, Santa Barbara.

Gineo, W.M. and S.W. Omamo. 1990. An analysis of household expenditures on nursery products in the United States. Southern J. Agr. Econ. 22(2):199-208.

Golf Course Superintendents Association of America. 1996. 1996 Golf course superintendents report. Golf Course Superintendents Assoc. Amer., Lawrence, Kans.

Henry, M.S. 1994. The contribution of landscaping to the price of single family homes: A study of home sales in Greenville, South Carolina. J. Environ. Hort. 12(2):65-70.
Hodges, A.W., J.J. Haydu, P.J. van Blokland, and A.P. Bell. 1994. Contribution of the turfgrass industry to Florida's economy, 1991/92: A value added approach. Econ. Rpt. 94-1. Food Resource Econ. Dept., Inst. Food Agr. Sci., Univ. Florida, Gainesville, December.

Johnson, D.C. and R.L. Christensen. 1995. The green industry today-some issues and future prospects. J. Agribusiness 13(1):63-76.

Kakutani, M. 1995. Tipping fees at California solid waste disposal facilities. Economic Res. and Forecasting Section, California Integrated Waste Mgt. Board, Sacramento, October.

Kross, B.C., L.F. Burmeister, L.K. Ogilvie, L.J. Fuortes, and C.M. Fu. 1996. Proportionate mortality study of golf course superintendents. Amer. J. Ind. Medicine 29(5):501-506.

Markets Page ${ }^{\mathrm{TM}}$. 1996. Recycling times, Environ. Ind. Assn., Washington, D.C., 9 Jan.

McPherson, E.G. and R.A. Rowntree. 1993. Energy conservation potential of urban tree planting. J. Arboricul. 19(6):321-331.

Medvitz, A.G. 1998. Urban growth squeezes agriculture. California Agr. 52(3):8-9.

Minnesota IMPLAN Group. 1997. 1994 IMPLAN Database, Stillwater, Minn.

National Association of College and University Business Officers. 1996. Summary data tablesCSU only. 1995 Benchmark Program, Natl. Assn. College and Univ. Business Officers, Washington, D.C..

National Christmas Tree Association. 1996. Consumer preferences and attitudes: 1995 Retail season, executive summary. Survey conducted by the Gallup Organization, Inc. for the Natl. Christmas Tree Assoc., Milwaukee, Wis.

National Gardening Association. 1996. National gardening survey 1995-1996. Conducted by the Gallup Organization, Inc., Natl. Gardening Assn., Burlington, Vt.

Pittenger, D.R., V.A. Gibeault, and S.T. Cockerham. 1991. Environmental horticulture: "Growth" industry in California. California Agr. 45(3):15-17.

Real Estate Research Council of Northern California. 1999. Northern California real estate report: Fourth quarter 1998. California State Polytechnic Univ., Pomona.

Rose, C. 1998. 1995 Statewide employment and payroll, SIC 0181, 0781, 0782, 0783, 3524, 5193, 5261, 5992, and 7992. Labor Mkt. Info. Div., Employment Dev. Dept., State of California, Sacramento, February.

Rosenberg, H.R. 1997. Groping for handles on the elephant: Where the farm jobs are and how much they pay in California. Labor Mgt. Decisions 6(1):9-12.

Schuch, U.K. and G.J. Klein. 1996. Wholesale nursery surveys reveal inventory, customers and business practices. California Agr. 50(5):1621.

State Board of Equalization. 1996. Taxable sales in California (sales and use tax) during 1995. 35th Annu. Rpt., Res. Stat. Div., California State Board Equalization, Sacramento.

Templeton, S.R., C. Brown, G.E. Goldman, S.J. Yoo, and V.S. Pradhan. 1999. An analysis of the horticultural economy in California. Working paper No. 883. Dept. Agr. Resource Econ. and Policy, Univ. California, Berkeley.

Templeton, S.R. and G. Goldman. 1996. Estimating economic activity and impacts of urban forestry in California with multiple data sources from the early 1990s. J. Arboricul. 22(3):131-143.

Templeton, S.R., D. Zilberman, and S.J. Yoo. 1998 An economic perspective on outdoor residential pesticide use. Environ. Sci. Technol. 27(1):416423.

Turner, S.C. and W. Kriesel. 1995. The relative importance of the green industry in the U.S. agricultural economy. J. Agribusiness 13(1):5162. 